\title{
The Relationship Between The Body Mass Index and The Pain Threshold in Myofascial Pain Syndrome: A Cross-sectional Study
}

\author{
Ibrahim Agung, Nyoman Murdana, Herdiman Purba \\ Department of Medical Rehabilitation Dr. Cipto Mangunkusumo National Hospital, \\ Faculty of Medicine, University of Indonesia, Jakarta-Indonesia.
}

\begin{abstract}
Introduction: The obesity on the myofascial pain syndrome (MPS) was reduced the pain thresholds, leads to decreasing of physical functioning and quality of life. The obese group was more sensitive to pain due to the proinflammatory condition. This study aimed to examined the relationship between the Body Mass Index (BMI) and the pain threshold in MPS patients.

Methods and Materials: This study was a cross-sectional study, conducted in an outpatient clinic of Medical Rehabilitation Department of Dr. Cipto Mangunkusumo Hospital, Jakarta. The subjects recruited consecutively. The pain intensity was assessed subjectively by the Visual Analogue Scale (VAS) score from 0 to 10 . The number of the trigger points (TP) were examined palpation manually. The pain threshold was evaluated by the algometer $(\mathrm{Kg})$ on the upper trapezius muscles.

Results: The study has recruited 30 patients, aged 40,5 (20-54). The BMI was $24.97 \pm 3.39 \mathrm{Kg} / \mathrm{M} 2$. The VAS score was 6 (5-8). The number of the TP was $5.83 \pm 1.74$. The pain threshold was $2.48 \pm 0.52 \mathrm{Kg} / \mathrm{cm} 2$. Most of the subjects have overweight $(20 \%)$ and obesity $(47 \%)$. There was no correlation between the BMI with the pain intensity $(r=-0.076, p=0.689)$, with the number of trigger points $(r=0.256, p=0.171)$ and with the pain threshold $(\mathrm{r}=0.189, \mathrm{p}=0.316)$.
\end{abstract}

Conclusions: Therefore the BMI was not related to the pain intensity, the number of trigger points as well as with the threshold of pain in the MPS patients. However, the number of the TP tends to increase, and the threshold of pain has the tendency to reduced in the obese subjects.

Keywords: Obesity; Myofascial Pain Syndrome; VAS; Pain Threshold

\section{Correspondence Detail:}

Ibrahim Agung

Email: ibrahim.kfr@gmail.com 


\section{INTRODUCTION}

Obesity defined as abnormal or excessive fat accumulation that presents a risk to health, by World Health Organization. ${ }^{1}$ Obesity determined by calculating Body Mass Index (BMI) through measuring body weight and body height. According to Asia Pacific criteria, normal BMI range is 18.5 to $22.9 \mathrm{~kg} / \mathrm{m} 2$, overweight is 23.0 to $24.9 \mathrm{~kg} / \mathrm{m} 2$, and BMI $\geq 25 \mathrm{~kg} / \mathrm{m} 2$ classified as obesity. ${ }^{2}$ WHO also stated that obesity is a global pandemic and the most common chronic problem in adults. ${ }^{1}$ In Indonesia, the prevalence of obesity, keeps increasing. Data from the Indonesian basic of the health research (RISKESDAS in 2013) showed that the prevalence of obesity is $19.7 \%$ in male adults and $32,9 \%$ female adults. In Jakarta, the prevalence of obesity is rising above the national prevalence. ${ }^{3}$ The data from Obesity Clinic in Medical Rehabilitation Department of dr. Cipto Mangunkusumo Hospital shows an increasing number of patients every year. There were 2.487 visiting patients in Obesity Clinic in $2014 .{ }^{4}$

Obesity is a risk factor that is related to many health problems, such as metabolic syndrome, cardiovascular disease, and cancer. ${ }^{1}$ Many studies have also shown that obesity is significantly related to chronic pain. Stone et al. conducted a study of one million populations in the United States to examine the association between obesity and pain. $^{5}$ The study concluded that BMI and pain have positively correlated, and people with obesity were more prone to have pain. This study also found that overweight group reported 20\% higher rates of pain than normal weight group, $68 \%$ higher for type I obese and $136 \%$ higher for type II obese. Hitt et al. examined the relationship between obesity and pain to 3.637 respondents. The study concluded that respondents with higher BMI are more likely to have pain. ${ }^{6}$ Respondents that classified as class I obese were 1.762 times more likely to report pain compared to normal weight. Class II obese subjects were 1.888, and class III obese respondents were 2.297 times more likely to report pain. This study also showed that obese respondents were more likely to report pain in multiple locations. Other studies with large sample size also reported the relation between obesity and chronic musculoskeletal pain such as low back pain, tension-type or a migraine headache, fibromyalgia and widespread chronic pain. ${ }^{7,8}$

One of the most common musculoskeletal problem in daily practice that causing chronic pain is myofascial pain syndrome (MPS). Myofascial pain syndrome is musculoskeletal pain that is caused by hyperirritable trigger point. ${ }^{9}$ The incidence of MPS is unrelated to race and can found throughout all age group with the most majority found in 27.5 to 50 years old. It estimated that $14.4 \%$ of people in the United States suffer from musculoskeletal pain with $85 \%$ is caused by MPS. ${ }^{9}$ The data from Medical Rehabilitation Department of dr. Cipto Mangunkusumo Hospital showed that 
there were 524 patients with MPS on the neck and shoulder in $2014 .{ }^{10}$

The mechanism between BMI and pain threshold is not well understood. One of the proposed mechanisms is that obesity is a pro-inflammatory state with a high level of inflammatory markers such as interleukin 6 (IL-6), tumor necrosis factor $\alpha$ (TNF- $\alpha$ ) moreover, C-reactive protein (CRP). This inflammatory condition contributes to pain and lower pain threshold. ${ }^{11-13}$ The other mechanism is leptin and ghrelin hormones metabolism disturbance in an obese individual because these hormones have a role in pain modulation and pain threshold..$^{8,14}$ Another mechanism is the disturbance in endogenic opioid, which regulate mood and pain. ${ }^{15,16}$

Obesity and MPS will cause pain threshold reduction, hence causing the patient more prone to have pain than healthy people. ${ }^{17,18}$ Many studies suggest pain threshold reduction in obese peoples. McKendall et al. in his study comparing 26 individuals with obesity and normal weight found that obese group was significantly more sensitive to pain suggesting low pain threshold. ${ }^{19}$ Zhang et al. in a crosssectional study with 2.517 healthy male adults, concluded that obese group the lower pain threshold. ${ }^{20}$ Okifuji et al. in his study of 215 fibromyalgia syndrome patient, concluded that obesity had a significant association with pain sensitivity compared to non-obese group. ${ }^{21}$

Myofascial pain syndrome is more common in the upper body part. Eighty-four percents of trigger points found in trapezius, scalene, levator scapula, and infraspinatus muscles. The trapezius muscle is the most commonly affected muscle in MPS accounting for $34 \%$ of cases. $^{9}$ Myofascial pain syndrome characterized by pain, pain threshold reduction, muscle spasm and range of motion limitation. ${ }^{22}$ Both obesity and myofascial pain syndrome will cause physical functioning decline and reduce the quality of life. ${ }^{23,24}$

Previous studies have proven the association between BMI and pain threshold reduction. However, a study that examines the relationship between BMI and pain threshold in MPS patient has not done. This study aimed to examine the relationship between BMI with pain intensity, number of trigger points and pain threshold in myofascial pain syndrome patients. Pain intensity was measured objectively using a visual analog scale (VAS), and pain threshold \ measured with manual standard pain threshold meter (algometer). 


\section{METHODS}

Study Design, Place and Participants

This study was a cross-sectional study, conducted in the outpatient clinic of Medical Rehabilitation Department of dr. Cipto Mangunkusumo Hospital, Jakarta, Indonesia. Thirty subjects included consecutively, aged 20-55 years old, diagnosed with MPS on the upper trapezius muscles. All of the subjects diagnosed with Travell, Simons and Simmons criteria for at least three months. Additional inclusion criteria included: Minimally two trigger points in upper trapezius muscles, with VAS $\geq 5$ that are not taking any analgesics and willing to participate in this study. Subjects with fibromyalgia syndrome, cervical radiculopathy or myelopathy excluded.

All collected data included demographics, clinical symptoms, assessment of pain intensity, and measures of number trigger points and pain threshold (by pain threshold meter/algometer). Each patient was assessed and measured by the same physician. Body mass index calculated as weight in kilograms divided by the square of the height in meters. Healthy body weight classified as BMI $18.5-22.9 \mathrm{~kg} / \mathrm{m}^{2}$, overweight as BMI 23.0-24.9 $\mathrm{kg} / \mathrm{m}^{2}$, and obesity as BMI $\geq 25.0 \mathrm{~kg} / \mathrm{m} 2$ using Asia Pacific criteria for BMI. All participants have given their written consent after received detailed information about the study.

\section{Measurements}

Pain intensity assessment

Both of local and referred pain are the most common symptoms in MPS and exaggerated by manual palpation on the trigger points. The Visual analog scale (VAS) Was used to evaluate the pain intensity. The visual analog scale is also an objective assessment to evaluate pain intensity in MPS patients. VAS has 0 to 10 scales, with number 0 means no pain, and number 10 means the worst pain intensity.

\section{Number of trigger points and pain threshold assessment}

Trigger points were assessed manually by palpation and pain threshold was measured with a manual algometer. Trigger points are a specific tender sign on myofascial pain syndrome. Patients were palpated manually on the upper trapezius muscles to determine trigger points according to Travell, Simons and Simmons criteria. The measured trigger points were the active trigger points, both of the nuclear trigger and peripheral trigger points in the surrounding muscle.

The number of trigger points calculated. The trigger points will be marked by ' $\mathrm{X}$ ' sign, and then the pain threshold was measured. The pain threshold was 
evaluated by the algometer meter, with a maximum load of $10 \mathrm{~kg}$. The algometer was placed perpendicularly to the trigger points and the pressure given to the trigger points, until the patients reported pain sensation with the threshold, as indicated by the pointed needle on the scale number $(\mathrm{Kg})$ in the Algometer.

Statistical analysis

All of the data were presented in tables and statistical analysis was done using SPSS v.20 for windows. Kolmogorov-Smirnov test was used to evaluate the normality of data distribution. The Spearman and Pearson correlation coefficients have assessed the relationship between variables. The Kruskal-Wallis test was used to analyze the pain intensity, and the ANOVA test used to analyze the number of trigger points and pain threshold in the three categories of BMI.

\section{RESULTS}

A general characteristic of subjects

The study population consisted of 24 females and six males MPS patients.

Table I. Demographic and clinical characteristic of subjects

\begin{tabular}{lcc}
\hline \multicolumn{1}{c}{ Variable } & Mean \pm SD & Median (range) \\
\hline Age (year) & - & $40.5(20-54)$ \\
\hline Onset (month) & - & $4(3-6)$ \\
\hline Body weight $(\mathrm{kg})$ & $63.30 \pm 8.33$ & - \\
\hline Body height $(\mathrm{m})$ & - & $1.57(1.49-1.74)$ \\
\hline Body mass index $\left(\mathrm{kg} / \mathrm{m}^{2}\right)$ & $24.97 \pm 3.39$ & - \\
\hline VAS score & - & $6(5-8)$ \\
\hline Number of trigger points & $5.83 \pm 1.74$ & - \\
\hline Pain threshold $\left(\mathrm{kg} / \mathrm{cm}^{2}\right)$ & $2.48 \pm 0.52$ & - \\
\hline
\end{tabular}

VAS: Visual Analogue Scale

The data have shown in Table 2 were described that the BMI was in normal category (24.97 \pm 3.39 ), and the pain intensity was $6(5-8)$ which mean the moderate pain. There were $5.83 \pm 1.74$ of TP numbers on the subjects, and the pain threshold by Algometer was $2.48 \pm 0.52 \mathrm{Kg} / \mathrm{cm}^{2}$. 
Table 2. Distribution of the Pain intensity according to the BMI

\begin{tabular}{llrrrr}
\hline \multirow{2}{*}{ Variable } & & \multicolumn{4}{c}{ BMI } \\
\cline { 3 - 6 } & Range & $\begin{array}{c}\text { Normal } \\
\mathbf{n = 1 0}(\mathbf{3 3} \%)\end{array}$ & $\begin{array}{c}\text { Overweight } \\
\mathbf{n = 6}(\mathbf{2 0} \%)\end{array}$ & $\begin{array}{c}\text { Obesity } \\
\mathbf{n = 1 4}(\mathbf{4 7 \%})\end{array}$ & $\boldsymbol{P}$ value \\
\hline Pain intensity & Median & $5-7$ & $5-6$ & $5-8$ & 0.509 \\
\hline & Mean (SD) & 5.00 & 5.50 & 6.00 & \\
\hline Number of trigger points & Range & $4-7$ & $3-8$ & $3-10$ & 0.394 \\
\hline & Median & 5.00 & 6.00 & 6.00 & \\
\hline & Mean (SD) & $5.30(0.83)$ & $5.67(2.07)$ & $6.29(1.15)$ & \\
\hline Pain threshold & Range & $2.00-3.00$ & $1.90-3.01$ & $1.00-3.30$ & 0.288 \\
\hline & Median & 2.32 & 2.00 & 2.79 & \\
\hline & Mean (SD) & $2.40(0.24)$ & $2.32(0.56)$ & $2.61(0.36)$ & \\
\hline
\end{tabular}

The data in the Table 2 have described the distribution of the data that there was same intensity of pain in all of the BMI groups. Although statistically there was no correlation between the number of TP and the pain threshold with the categories of BMI, the number of TP were slightly higher in the obesity group compared to the overweight, and the normal group, as well as the pain threshold, has showed decreased in the obesity compared to overweight and healthy group.

Table 3. Correlation coefficients between BMI and assessment of pain intensity, number of trigger points and pain threshold

\begin{tabular}{lll}
\hline \multicolumn{1}{c}{ Variable } & r & p \\
\hline BMI- Pain intensity & -0.076 & 0.689 \\
\hline BMI-Number of trigger points & 0.256 & 0.171 \\
\hline BMI-Pain threshold & 0.189 & 0.316 \\
\hline
\end{tabular}

The data in Table 3 has described no significant correlations between the BMI and the pain intensity, the number of trigger points and the pain threshold.

\section{DISCUSSION}

The present study found that increased BMI is common in myofascial pain syndrome. Almost half of our subjects are obese with an additional $20 \%$ in the overweight category. The earlier study has found that the BMI was not the relationship with the pain intensity, the numbers of trigger points and the pain threshold in MPS patients. ${ }^{25}$ In contrast with the study by McKendall reported that the obese subjects have more sensitive on pain threshold 
than non-obese subjects. ${ }^{19}$ Study by Neumann et al. on the 100 female were diagnosed with fibromyalgia syndrome, has a conclusion that an increased of the BMI was significantly related to lower quality of life, physical functioning, higher point count and low pain threshold. ${ }^{26}$ Many studies have explained that the correlation between BMI and pain threshold were still controversy. Some studies have shown the relationship between those variables. Nevertheless, the other studies have an opposite result.

This study result has found that the higher of BMI was not related to the higher pain intensity and lower pain threshold in myofascial pain syndrome. However, the distribution of data in Table 2 has shown that the higher BMI has the slightly higher number of trigger point, and lower of the pain intensity threshold as well. This result study might cause an insufficient of the number of the subject. A study by Icagasioglu et al. on 80 subjects have found that there was no significant difference in pain threshold between obese and non-obese patients. ${ }^{27}$ Dodet et al in their study of 31 Obese individuals and 49 non-obese individuals, reported that obese individuals have a higher pain threshold. ${ }^{15}$ Torensma in their study of 41 subjects with obese morbidity and 35 control subjects, also reported that obese subjects have higher pain threshold than control subjects. ${ }^{28}$ There has no clear mechanism could explain the higher pain threshold in the obese individuals. ${ }^{29}$ One of the possible explanation caused by the fat tissue that covered the nerve fibers acted as the pain insulator. ${ }^{27}$ Another explanation was the neuropathy in the small nerve fibers in an obese patient, which caused decrease sensitivity of pain. ${ }^{28,30}$

The Results of this study has revealed that there was no correlation between the BMI with the pain intensity, the number of the trigger point, and the pain threshold. Many factors can contribute to myofascial pain syndrome, such as the age. A study by Taufik hat has a similar age of subjects with this study has found that the age subjects were in productive age category, that more exposed to repetitive and overuse activity as the risk of the MPS. ${ }^{31}$

The other factor that can contribute to the risk was sleep quality. The previous study has found that lack of sleep quality has correlated to the muscle pain. There were studies in humans that found the Relationship between pain and sleep quality. The mechanism that can explain; the sleep disorders can increase the pain, and turn back to caused the sleep disorders. Many studies on sleep disturbance and musculoskeletal pain have revealed the various types of pain on subjects, such as a headache, neck pain, back pain, and fibromyalgia syndrome. On subjects who have a good sleep might have the decreased of muscle tone on deep sleep, in contrast in patients with poor quality of sleep, the muscle was never relaxed and become tenser, and as the results were increasing the muscle pain. ${ }^{32}$

There is a tendency towards higher pain thresholds (and consequently a lowered pain sensitivity at lowintensity stimuli) in obese subjects. According to Miscio et al., and Dodet et al. many physiological changes 
associated with obesity may affect pain pathways, causing possible altered pain sensitivity. This study suggests that the pain sensitivity threshold may be affected by factors such as cognition (e.g., intelligence level) and social, economic status Belsky et al. and Tchicaya et al. conclude in their studies that there is a relationship between obesity, lower intelligence level, and lower social, economic status. However, none of the included studies in this systematic review evaluated to cognition, social, and the economic status may have influenced pain perception. ${ }^{33}$

The gender was a risk factor as well, which the majority of patients with MPS in This study was female. This result was similar to the previous studies have found that the female has a lower pain threshold due to iron deficiency in a period of the menstruation . ${ }^{34-36}$ The other factor was the smaller muscle in the female on neck region, along with lower muscle strength compared to the male, addressed the female more venerable to the MPS. The study by Yoo has found the stronger association between fat mass and pain in the female. ${ }^{37}$

The study by Neumann et al. found that the higher BMI in fibromyalgia patient associated with higher number of tender points. ${ }^{26} \mathrm{~A}$ cross-sectional study by Hitt on more than three thousand subjects in the United States has shown that higher BMI significantly associated with the higher number of pain locations. ${ }^{6}$ The resulting study has no correlation between the BMI with the number of the trigger point statistically. However, the distribution of the data has revealed the higher number of the trigger point in the obesity group.

The limitation of the study was the small sample size, the unequal distribution between gender, the large discrepancy of the subjects aged, and uneven distribution of the subject number in the category of BMI. Further study was necessary to analyze another factor that has a contribution to the pain threshold in myofascial pain syndrome.

\section{CONCLUSION}

Although by statistic there was no correlation between the BMI with the pain intensity, the number of trigger points, and the threshold of pain, this study has found that there were increasing on the number of trigger points, beside the lower of the pain threshold in the higher BMI groups. So can be suggested that the increase of BMI should be considered to prevent in the MPS management.

\section{REFERENCES}

1. World Health Organization. Obesity and Overweight: Fact Sheet No 311;2015. Available from: http:// www.who.int/mediacentre/factsheets/fs311/en/. Accessed September 1, 2017. 
2. WHO Expert Consultation. Appropriate body mass index for Asian populations and its implications for policy and intervention strategies. Lancet. 2004 Jan 10;363(9403):157-63.

3. Riskesdas. Riset Kesehatan Dasar. Badan Penelitian Dan Pengembangan Kesehatan Kementrian Kesehatan RI. 2013.

4. Loekito N, Tamin TZ, Murdana N, dkk. Perbandingan pengaruh latihan di air dibandingkan latihan di darat pada penderita obesitas dengan osteoarthritis lutut dalam penurunan intensitas nyeri dan peningkatan kekuatan otot lutut. [tesis]. Jakarta: Universitas Indonesia; 2017.

5. Stone AA, Broederick JE. Obesity and Pain are Associated in the United States. Obesity 2012; 20: 1491-1495.

6. Hitt HC, McMillen RC, Thornton-Neaves $\mathrm{T}$ et al. Comorbidity of obesity and pain in a general population: results from the Southern Pain Prevalence Study. J Pain 2007; 8:430-6.

7. Wright LJ, Schur E, Noonan C, et al. Chronic pain, overweight, and obesity: findings from a communitybased twin registry. J pain 2010 July; 11(7): 628-635.

8. Narouze S, Souzdalnitski D. Obesity and chronic pain: a systematic review of prevalence and implications for pain practice. Regional Anesthesia and Pain medicine 2015; 40(2): 91-111.

9. Travell, J.G., and Simons, D.G. Myofascial pain and dysfunction: the trigger point manual. Baltimore: Williams and Wilkins. 2012. 5-201.

10. Agung I, Murdana N, Purba H. Perbandingan efektivitas terapi laser tenaga rendah dengan terapi dry needling pada penderita sindroma nyeri miofasial otot upper trapezius: studi intervensi. [tesis]. Jakarta: Universitas Indonesia. 2017.

11. Ray L, Lipton RB, Zimmerman ME, Katz MJ, Derby CA. Mechanism of the association between obesity and chronic pain in the elderly. 2011;152:53-9.

12. McVinnie DS. Obesity and pain. British Journal of Pain 2013; 7(4): 163-170.

13. Astita RA, Tashani OA, Sharp D et al. Argument for the need of investigation of the relationship between body fatness and experimental pain sensitivity. Libyan J Med 2015; 10: 28457.

14. Guneli E, Gumustekin M, Ates M. Possible involvement of ghrelin on pain threshold in obesity. Med Hypotheses. 2010; 74(3):452-454.

15. Dodet P, Perrot S, Auvergne L, et al. Sensory impairment in obese patients: Sensitivity and pain detection thresholds for electrical stimulation after surgery-induced weight loss, and comparison with a non-obese population. Clin J Pain. 2013;29(1):43-49.

16. Okifuji A, Donaldson GW, Barck L, Fine PG. The relationship between fibromyalgia and obesity in pain, function, mood, and sleep. J Pain. 2010; 11(12):1329-1337.

17. Okifuji A, Hare BD. The association between chronic pain and obesity. Journal of Pain Research. 2015; 8: 399-408.

18. Timmerman GM, Calfa NA, Stuifbergen AK. Correlates of body mass index in women with fibromyalgia. OrthopNurs: 2013; 32(2): 113-119.

19. McKendall MJ, Haier RJ. Pain sensitivity and obesity. Psychiatry Res. 1982; 8:119-25.

20. Zhang Y, Zhang S, Gao Y et al. Factors associated with the pressure pain threshold in healthy Chinese men. Pain Medicine 2013; 14: 1291-1300.

21. Okifuji A, Donaldson GW, Barck L, Fine PG. Relationship between fibromyalgia and obesity in pain, 
function, mood, and sleep. J Pain. 2010;11(12):1329-1337.

22. Rachlin E, Rachlin I. Myofascial pain and fibromyalgia, $2^{\text {nd }}$ ed. Missouri. Mosby 2002; 201-215,231258.

23. Arranz L, Canela MA, Rafecas M. Relationship between body mass index, fat mass and lean mass with SF-36 quality of life scores in a group of fibromyalgia patients. RheumatolInt 2012;32: 3605-11.

24. Arranz L, Rafecas M, Alegre C. Effects of obesity on function and quality of life in chronic pain conditions. CurrRheumatol Rep 2014; 16: 390.

25. Miscio G, Guastamacchia G, Brunani A, et al. Obesity and peripheral neuropathy risk: a dangerous liaison. J Peripher Nerv Syst JPNS. 2005. 10:354-8.

26. Neumann L, Lerner E, Glazer Y, et al. A cross-sectional study of the relationship between body mass index and clinical characteristics, tenderness measures, quality of life, and physical functioning in fibromyalgia patients. ClinRheumatol 2008; 27: 1543-7.

27. Icagasioglu A, Turgut ST, Atlig RS et al. Impacts of obesity on pain threshold, depression and quality of life. Acta Medica Mediterranea 2015; 31: 43.

28. Torensma B, Oudejans L, Velzen M. Pain sensitivity and pain scoring in patients with morbid obesity: Surgery for obesity and related disease. 2017. 13: 788-795.

29. Torensma B, Thomassen I, Velzen $M$ et al. Pain experience and perception in the obese subject systematic review (revised version). ObesSurg. 2016. 26: 631-639.

30. Hozumi Jun, Sumitani M, Matsubayashi Y et al. Relationship between neuropathic pain and obesity. Pain research and management. 2016

31. Taufik Nora. Perbedaan efek terapi antara penggunaan dua ukuran jarum dry needling terhadap penurunan nyeri dan tenderness pada sindrom nyeri miofasial otot upper trapezius tipeaktif. [tesis]. Bandung: UniversitasPadjadjaran. 2013

32. Kim SA, Yang KI, Oh KY, Hwangbo Y. Association between sleep quality and myofascial pain syndrome in Korean adults: Questionairre based study. 2014. Journal of Musculoskeletal Pain. 22(3): 232-236

33. Torensma B, Thomassen I, Velzen M, Alexander B. Pain experience and perception in the obese subject systematic review (revised version). 2015. New York: Springer Science

34. Lofriman. Perbandingan efektivitas antara terapi kompresi iskemik dengan spray \& stretch terhadap penurunan nyeri pada penderita nyeri myofascial otot upper trapezius. [tesis]. Jakarta: Universitas Indonesia. 2007.

35. Saefulloh A. Perbandingan efek superficial dry needling dan deep dry needling terhadap penurunan derajat nyeri pasien dengan sindroma nyeri miofasial. [tesis]. Jakarta: Universitas Indonesia. 2006.

36. Barboza, CA, Rocha, LY., Caperuto, EC, Irigoyen, MC, Rodrigues B. Impact of exercise training and detraining after myocardial infarction: a literature review. São Judas University .2012

37. Yoo JJ, Cho NH, Lim SH, Kim HA. Relationships between body mass index, fat mass, muscle mass, and musculoskeletal pain in community residents. Arthritis Rheumatol. 2014. 66(12):3511-3520. 